L'étude de la sorcellerie.

LA XIVe Semaine de Missiologie s'est tenue à Louvain du 27 au 30 août. Elle fut consacrée entièrement à l'étude de la sorcellerie. En principe rapports et discussions n'etaient pas limités aux missions d'Afrique, s'étendaient au contraire au monde missionnaire tout entier. En fait cependant les missions africaines s'y sont trouvées encore cette année à l'avant-plan.

En dehors du discours d'ouverture du secrétaire général de la Semaine, le R. P. Charles, dans lequel il esquissait le thème général que la Semaine s'était proposé d'étudier, la notion de sorcellerie fut examinée plus particulièrement par le Dr Van Bulck du point de vue ethnologique, par le Dr K. Bellon, professeur à l'Université de Nimègue du point de vue de l'étude comparée des religions, par le Dr J. Creyghton, professeur à l'Université Grégorienne de Rome du point de vue de la théologie morale. Ces exposés théoriques furent suivis de communications faites, pour la plupart, par des religieux ayant derrière eux une longue carrière missionnaire. Signalons particulièrement pour l'Afrique: 'La sorcellerie en A.E.F.', par le R. P. Auzanneau, 'La sorcellerie appelée Kindoki', par Mgr Cuvelier, 'Les sorciers comme chefs de rebellion', par le R. P. Dufonteny, 'Sorciers et devins guérisseurs à Madagascar ' par le R. P. Nicol, 'Anioto et Mambela', par le Prof. Moeller, 'Beheksing bij de Barundi', par le Dr Zuure, 'Zwarte tooverij bij de Noord-Transvaalsche Bavenda', par le R. P. Peleman, 'De christelijke leer over ongeluk en dood in den strijd tegen het Buloji', par Mgr De Clercq, 'Europeesche magie in Afrika' par le R. P. Monnens.

En confrontant ainsi les considérations théoriques avec les connaissances pratiques, la Semaine réalisa merveilleusement le but principal qu'elle se propose, notamment, de fournir aux missionnaires l'occasion de mettre en commun leurs expériences et d'en faire bénéficier tous ceux qui s'intéressent pratiquement aux missions. (Communication du PROFESSEUR N. DE CLEENE.)

\title{
Introduction à la loi Nyakyusa (Résumé de l'article pp. 16-36)
}

PourQuor l'homme conforme-t-il généralement sa conduite aux us et coutumes de ses amis et de ses voisins? D'abord parce qu'entre les membres d'un groupe social il y a une cettaine entente ou communauté d'intéêtét; et, ensuite, à cause de l'opération de sanctions. Celles-ci sont de différentes natures, parmi lesquelles l'action légale.

On peut définir l'action légale comme une action habituelle d'un ou de plusieurs membres à un groupe social en vue de maintenir un type de conformité sociale, d'assurer le cours des activités humaines dans la voie habituelle propre à ce groupe particulier. L'action légale relève d'une institution, c.-à-d. elle se répète régulièrement et elle implique une action combinée de deux ou plusieurs membres de la société; elle est légale dans son dessin délibéré de conserver l'ordre social, et dans sa forme elle inclut toujours l'action d'une personne non directement intéressée au litige. 
Parmi les Nyakyusa, la conformité sociale est fréquemment attaquée, soit par des actes qui la battent en brêche, soit par des situations qui la menacent. Plusieurs de ces actes et de ces situations provoquent l'action légale.

L'action légale est distincte des sanctions religieuses de la morale, des sanctions économiques de politique commune, de la force qui réside dans la louange et le blâme de ses congénères. Distinguer ces différentes sanctions ne signifie pas cependant qu'en fait elle n'opèrent pas normalement ensemble.

La force spécifique de l'action légale réside d'abord dans l'autorité de ceux qui agissent et ensuite, pour chaque cas particulier, dans l'accord général avec leur action.

\section{CONTRIBUTORS TO THIS NUMBER}

\section{COLLABORATEURS}

\section{MITARBEITER}

Professor N. De Cleene, Ph.D. (Louvain): Lecturer in Psychology and Ethnology at the Colonial University of Antwerp, Lecturer in Ethnography of the Congo at the École Coloniale of Brussels and the University of Ghent, Associated Member of the Institut Royal Colonial Belge; held a Rockefeller Research Fellowship for field work in the Belgian Congo.

Mr. G. B. Wilson, B.A. (Oxon): At present engaged in field work among the Konde in Tanganyika Territory; holds a Fellowship from the Rockefeller Foundation; previously held an Institute Studentship for work in anthropology under Professor Malinowski at the London School of Economics.

Mr. S. J. K. BAKER: Lecturer in Human Geography at the University of Liverpool; in I 933 visited East Africa under the auspices of the British Association Research Committee on the Human Geography of Tropical Africa.

Miss HrLDA BEEMER : At present engaged in field work among the Swazi as holder of an Institute Fellowship.

Dr. H. S. MekeEL, M.A. (Chicago): Field Representative in charge of Applied Anthropology at the Office of Indian Affairs, United States Department of the Interior, Washington.

Mr. R. M. EAST, B.A. (Oxon) : Superintendent of Education in charge of the Translation Bureau, Zaria, Nigeria; held an Institute Studentship for linguistic studies; author of Stories of Old Adamawa and readers, \&c., in Nigerian languages. 